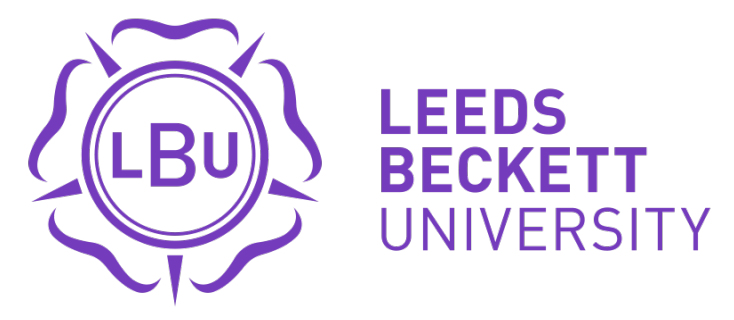

Citation:

Beniston, L and Ellwood, P and Gold, J and Roberts, J and Thorpe, R (2014) Innovation development - an action learning programme for medical scientists and engineers. Action Learning: Research and Practice, 11 (3). pp. 311-329. ISSN 1476-7333 DOI: https://doi.org/10.1080/14767333.2014.945896

Link to Leeds Beckett Repository record:

https://eprints.leedsbeckett.ac.uk/id/eprint/4720/

Document Version:

Article (Accepted Version)

The aim of the Leeds Beckett Repository is to provide open access to our research, as required by funder policies and permitted by publishers and copyright law.

The Leeds Beckett repository holds a wide range of publications, each of which has been checked for copyright and the relevant embargo period has been applied by the Research Services team.

We operate on a standard take-down policy. If you are the author or publisher of an output and you would like it removed from the repository, please contact us and we will investigate on a case-by-case basis.

Each thesis in the repository has been cleared where necessary by the author for third party copyright. If you would like a thesis to be removed from the repository or believe there is an issue with copyright, please contact us on openaccess@leedsbeckett.ac.uk and we will investigate on a case-by-case basis. 


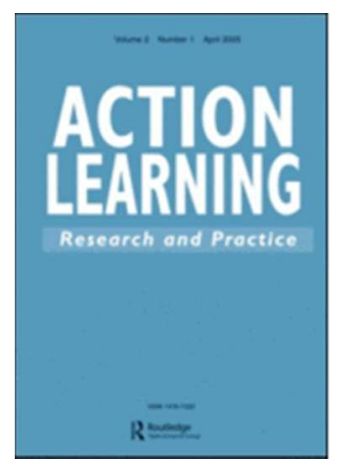

\section{Innovation Development - An Action Learning Programme for Medical Scientists and Engineers}

\begin{tabular}{|r|l|}
\hline Journal: & Action Learning: Research and Practice \\
\hline Manuscript ID: & Draft \\
\hline Manuscript Type: & Refereed Paper \\
\hline Keywords: & $\begin{array}{l}\text { action learning, critical reflective practice, innovation management, higher } \\
\text { education }\end{array}$ \\
\hline
\end{tabular}

\section{SCHOLARONE \\ Manuscripts}




\title{
Innovation Development - An Action Learning Programme for Medical Scientists and Engineers
}

\begin{abstract}
There is increasing evidence that action learning is valuable in a higher education setting. This paper goes on to report a personal development programme, based on principles of critical action learning, where the aim is to equip early-career scientists and engineers working in a university setting with the knowledge, skills and confidence to approach the management of innovation. After learning about action learning and critical reflection, the participants, all post doctorate researchers, completed innovation projects at work, meeting in action learning sets as they proceed. We explain a method of critical thinking before reporting results from an evaluation study based on interviews and focus groups. We consider examples of projects undertaken before considering challenges for students with this approach to learning. Challenges included scepticism about the usefulness of management literature, difficulties in finding 'problems' within the constraints of post-doctoral work, and the discomfort and intensiveness of action learning. However, through adaptation by the tutors with students, some significant results were achieved.
\end{abstract}

Keywords: Action learning, critical reflective practice, innovation management, higher education

\section{Introduction}

Action learning, with peer learning at its heart, has long been a method favoured by educationalists where the development of practice is key. There is increasing evidence that action learning is valuable in a higher education setting, for the very fact it offers both knowledge and self-development to the learners in the process. Because of its relative autonomy (Brook et al, 2013), it offers a variety of pedagogical forms each linked to appropriate learning outcomes. It can be used with students (Lawless 2008; Boak 2011), with organisations in partnership with HE institutions offering 
accreditation (Harrison and Edwards 2012) or as a way of developing more critical educational programmes (Trehan and Rigg 2007). Whilst an action learning approach can often legitimately claim to address concerns about the relevance of higher education programmes for practitioners, there is an alternative argument that they fail to meet expectations in relation to rigour. This dilemma is manifest in the designing of programmes where the desire to make the programme content responsive to a learner's issues can come into conflict with institutional requirements to deliver a curriculum where there course content is specified. Revans (1982), the doyen of action learning, would have recognised this quandary as a tension between Q, or questioning insight, and $\mathrm{P}$, programmed knowledge. Revans argued that too much emphasis is placed on $\mathrm{P}$ and not enough on Q. In addition he would argue that where judgement is required and in circumstances where rational analysis is not possible emphasis needs to be increasingly driven by the interests of the learner. Always prepared to confront conformity he would often denounce the preoccupation many academics had with $\mathrm{P}$ as well as those involved in its delivery, noting that $\mathrm{P}$ is also the first letter of professor, platitude and poppycock (cf. Mumford 1995). Of course less certainty does present challenges to educators as content needs to be tailored to the needs of learners, and new skills have to be accumulated for the tutor to be effective. Those who have undergone this transition will claim that new skills are developed as old ones become less important as a shift takes place from; in power over, to in partnership with; from talking to listening; from expert to exemplar; and from teaching to facilitating. The ambiguities and tensions are particularly problematic when learners are used to working with problems that have a solution and the expectation, in scientific terms at least, for a theory to be proven or even true. Action learning privileges problems where there is no one correct answer or approach. 
This paper goes on to report a personal development programme where the aim is to equip early-career scientists and engineers working in a university setting with the knowledge, skills and confidence to approach the management of innovation in their professional lives. From the outset therefore the programme is as much about personal development in the context of their job as it is about knowledge for its own sake. As a consequence, the foundation of the programme is predicated on the practices of action learning (Pedler, 2012) which in this case, includes attempts to develop the skills of critical reflection within the participants (Gold et al 2002; Anderson and Thorpe, 2007). This programme forms part of a more extensive collaboration between a University Business School and a Medical Technologies Innovation Centre based at a research-led university in the UK. This centre established in 2009 to accelerate the commercialisation of medical technologies, comprises a network of innovation professionals: technology development managers, scientists, engineers, clinicians, intellectual property specialists and commercialisation managers. While it is clear that innovation management is a central part of the work of the Centre, very often it is the conduct of medical science that takes precedence in day-to-day activities of the researchers. As has been already noted, action learning as a method might be expected to be challenging to those from scientific/technology backgrounds who have more traditional expectations of what programs should look like. Reg Revans himself came from such a background (See Revans 1978). His theory of action is expressed as a science of praxeology one which assumes scientific rationality and logical reasoning. Despite such antecedents, applying these principles to managing and especially to action and change is a fairly challenging prospect; arguably especially so for scientists. In this paper, we relate how the programme was designed and implemented, including 
the way 'tools' were used to help participants think and reflect more critically. We then report the results of an evaluation of the programme, showing some of the benefits but also some of the challenges. Most significantly in this regard was being able to respond to the expectations on the part of the scientists in terms of what they thought constituted a programme in innovation management.

\section{Programme Design}

The Programme is run over a period of twelve months. As indicated above it is founded on the principles of action learning but it includes elements of critical action learning (CAL). Whilst there is no strict definition of action learning (Pedler, 2008), the approach taken in the design focused on an individual with a problem that could be shared with a small group of peers. Through a process of questioning, this group sought to challenge and support the individual with the objective of helping them to take action and by doing so improve the issues and dilemmas they faced. If there was an emphasis, this lay in helping participants better understand the problems they faced, especially in situations where there were no clear answers or answers are unknowable. Following the process of establishing the nature of the challenge they faced, each individual was encouraged to use the knowledge, discussion and processes in place it within the programme in order to agree a course of action they wished to take. This process is repeated for each member of the group, who then agree to meet again to review the results of the actions taken. This process becomes 'critical' when, in the course of surfacing a problem and understanding the issues that surround it, they become aware of a number of assumptions held by participants, perhaps also how their ideas came into being and how they might be changed - as previously they may well have lain hidden (Trehan and Pedler, 2009). 
While action learning provided the core process, as a University with a strong reputation for science and technology, 'experts' who could stimulate the students' interest in innovation management surrounded us. While such expertise could be construed as programmed knowledge or ' $\mathrm{P}$ ' (Revans 1978), our view was that this expertise or not to be devalued or ignored. As a consequence, although our approach was very much driven by the problems of the learners, we also encouraged them to appreciate the expertise that was available in their University and to be able to draw on it as they addressed practice based challenges. The shape of the programme that emerged is summarised in Figure 1.

Insert Figure 1 here

Central to the programme is the student's development of a work-based project. These projects were discrete activities that typically existed within larger innovation projects, provided a vehicle and opportunity for participants to 'try out' new (for them) activities. All programme participants were already involved in one or more university innovation project(s) giving each a strong touchtone to practice and application. We asked students to view these projects as 'data' and through them, their opportunity to test and develop what they had learnt about innovation. The other elements of the programme acted to support these projects. Seminar inputs were also used to introduce students to the more established ideas and literatures of innovation management. At the beginning of the programme these covered fairly generic topics such as 'project management' and 'leadership' and these were offered in a practitioner-friendly manner rather than being overly theoretical or academic in nature. Once the participants' 
projects began, their choice of seminar topics became prompted by the ideas and challenges that emerged from their own work. This required tutors to be on their toes, as there was no standard curriculum of topics, and beyond the initial few sessions tutors need to respond flexibly in the way they identified relevant topics and speakers. Given the idiosyncratic nature and technical orientation of many of the projects, the seminars sought to engender an open-ended interest in innovation, and provide a gateway into new (to them) and often highly diverse literatures. It was expected that through this process participants would be stimulated to engage with the more specialist/academic literature that aligned more appropriately with their emergent project challenges. In this manner we sought to make our knowledge inputs a way of offering additional stimulation to the action learning process. These emergent topics included those that are overtly concerned with innovation (e.g. Commercialisation of university science, creativity, NPD processes, prototyping and so on). There were also those that had a more general management flavour (e.g. team dynamics, quality management systems, social network analysis). Both academics and practitioners provided the seminar talks themselves. The academic's presentations sought to highlight key concepts and to provide a route into the literature on the topic as a prelude to self-directed study. The practitioner inputs aimed to provide case studies of how particular innovation concepts had been applied in practice.

The practical work undertaken in relation to the students' innovation projects and the reflective work that formed part of the students of self-study were always brought together in the conduct of Action-learning Sets. Sets were constituted as groups of 5-7 individuals, each having a dedicated facilitator, whose role was to help and manage the learning process. This was primarily focused on helping individuals to surface their individual and collective innovation needs, engender an appropriate 
learning culture, draw out from members their questions, and hold participants to account for taking action. The Action Learning sessions also required each student to report on his or her project work and allowed for progress on action to be monitored. This provided the cue for general discussion of the innovation management issues raised. The discussion concluded with the student making some commitment to take action (which they then reported at the next action learning session).

The programme assessment involved three-parts. Students commented that the three assignments proved crucial to them being able to integrate the diversity of knowledge acquired over the period of the programme. Each assignment had a different focus: the first assessed the students' ability to use tools to foster critical reflection and was timetabled after month 4 of the programme. This assignment also served to identify the major innovation theme that the student wished to explore for the remainder of the programme. The second (and most important assignment) comprised a critically reflective account of learning that had taken place during the work-based project. This assignment was structured around four work-based activities that constituted the students exploration of their chosen innovation theme. The third and final assignment required individuals to undertake a learning review across the whole programme.

\section{Tools for thinking that aid critical reflection}

At the outset of the programme, and to support the participants in identifying suitable work-based projects, exercises were run within the Action Learning Sets that sought to develop the participants' skills for critically reflecting on their work practices. This method combined a number of 'tools' that serve to help the participants be more reflective. One was argumentation analysis (Toulmin, 1958), along with approaches to 
story-telling (Gold et al., 2002), categories of critiques of management practice (Mingers, 2000) and cognitive mapping (Eden et al, 1983). Participants were taken through a critical reflection method during a workshop and asked to repeat it a number of times in private study. The aim here was to equip individuals with the skills to deconstruct their own professional practice as a prelude to identifying areas for development and action. A second workshop employed a cognitive mapping tool that served to facilitate the participants' sensemaking. This involved mapping a large number of reflections and ideas that they had generated to produce a complex cognitive map of ideas, issues, strategies and emotions. From this map clear priorities for action could be discerned and plans for action developed.

This method starts with them writing a short narrative on some aspect of their professional practice; quite simply something they had done during the previous 24 hours. This account or "story" was then examined for its underlying argumentation structure (Toulmin, 1958). In order to bring out those elements of critique to professional practice proposed by Mingers (2000) the programme adopted a process that brought each critique to bear through the following method:

(1) Surfacing claims

The students are asked to write a number of sentences that start "I believe that...". These beliefs are positioned as "claims" within their argument structure.

(2) Uncovering the rhetorical structure used in the claims For each "claim", the student is asked to provide 2 or 3 pieces of "evidence" (such as related facts or feelings) that validate the "claims". At this point, students are asked to pause and critique the soundness of the logic that connects 
their "evidence" to their "claims". This is Mingers" "critique of rhetoric" (2000).

(3) Uncovering critiques of tradition The arguments are then written in the form "I believe... because...". The students are asked to select any of the arguments that interest them, and then identify the "warrant" that allows them to use its "evidence" to make the "claim". In doing this they are asked to surface the assumptions they are made about longstanding practices. This is the "critique of tradition" (Mingers, 2000).

(4) Uncovering critiques of authority For each assumption that they articulate, the students are asked to question whether it is actually reflecting a particular point of view. This is the "critique of authority" (Mingers, 2000).

(5) Surfacing critiques of knowledge Pausing to examine the whole argumentation structure they have created, the students are asked to pose themselves the question "so what?" and to write down three learning points from the whole exercise. Asking them to consider the influence of their own personal context on all that they have identified, and how another person might have explained things differently, allows an exploration of the contextual and subjective nature of their knowledge of the social world. This is the "critique of knowledge" (Mingers, 2000). 
(6) Finally, the students are asked to repeat the whole exercise on three more occasions at weekly intervals, and to bring all the associated written work to the next session.

The next stage in building the students critical reflection skills involves working with the mass of reflections that they have gathered from this first mapping exercise. Drawing from some of the writings of the philosopher, Wittgenstein (1953), we introduce participants to a notion that they would encounter on many occasions with the management studies literature: the distinction between the problems of meaning and the problems of use of management theories (Gold et al., 2006). Problems of meaning in management are intellectual in character and search for generic 'best' solutions to a problem. By contrast, Problems of use are more local and proceed from the practical requirement to get things done. In seeking to generalise or theorise management experience, ideas are created which while potentially useful to the practising manager, can risk 'blinding' them to the important aspects of their personal situation. This risk of aspect blindness can stem from the prejudicial use of management concepts, which results in problems being viewed as ones of meaning (requiring answers that are coherent in terms of models and prescriptions) rather than use (requiring an awareness of our deep experience and re-experience of a situation). The second part of our critical reflection method is designed to help students see connections from what at first might appear (because of their aspect blindness) to them as isolated and unconnected views or incidents; a process labelled aspect dawning by Wittgenstein (1953). This provides the possibility for approaching innovation practice differently: seeing things anew and taking a different stance. This second element of the method uses a chart in the general format shown in Figure 2 to place the key learning points from each of the four critiqued stories from the first part. 
Insert Figure 2 here

The key points from the four stories are placed on the chart. Re-reading and writing the stories in this manner generates the realisation of connections that are captured in the left hand margin as 'patterns'. As the network of relationships continues to be built new understandings are recorded as insights and enduring problems as puzzles. At any point in this work, suggestions for action are noted in the bottom right hand box.

In this manner, the students can appreciate the richness of their practice for its own sake without first requiring management theory as the crucial sensemaking device. For this reason the knowledge inputs during the seminar sessions had a clear practitioner-orientation, rather than overburdening the students with too much strong management theory. Seminar talks were highly practical in nature and we encouraged students to use theoretical papers encountered during their private study as provocations for further practical insight. Crucially, the emphasis in this programme, was that such theories did not form an all-encompassing perspective for the way in which the students were encouraged to understand their practice of innovation. The following quote describes how one particular student made use of this process with the process also being illustrated in Figure 3.

\footnotetext{
"Evaluating the critical reflective practice exercise on my own experiences has brought several issues to light. The insights described in the chart [Figure 3] reveal themes that have occurred within my own work ethic before. The fact that I conceptualise new ideas frequently and lack concentration on a particular subject is a continuing quandary I need to address. Having reflected on the action points I have mapped on the chart, focus on certain aspects of my research has been prioritised. Instead of immediately embarking on a new technique to use, I have
} 
applied a critical reflective model to the ideas I propose to use in my experiments. This has had a profound effect on my project, in the direction it takes and the time needed for completion.”

\author{
Insert Figure 3 here
}

\begin{abstract}
These critical reflection routines were used over and over again during the programme as students reviewed their practice of innovation within their work-based projects.
\end{abstract}

\title{
Findings
}

The programme initially began in 2011 as a pilot without a recognised qualification at the end. Towards the end of the pilot and into 2012 the programme received university accreditation and the majority of the first cohort transferred to it. A second cohort started during the academic year 2013. The programme was initially directed towards University scientists at the post-doctoral level. However, due to feedback after the first cohort, the programme is now limited to post-docs with at least one years' experience. New post-doctoral researchers reported difficulties in reflecting on innovation practices that they were only then experiencing for the first time. It seems that participants in the programme needed a small, established stock of innovation experiences before they could work through the programme's reflection routines.

To understand the effectiveness of a CAL approach with such innovation professionals we subsequently held a series of interviews and focus groups with the students. The first cohort comprised a total of 8 early-career post-doctoral researchers with a further 5 participants either dropping out or transferring to the second cohort. All of these students were interviewed. Cohort 2 which began in 2013 had 16 participants 
in total. These students both participated in the interviews and in a focus group

discussion. At the time of the interviews, cohort 2 students had only reached first phase of the programme (up to assignment 1 - see Figure 1) and therefore their responses were more limited.

\section{Examples of Student Projects}

This sub-section offers an indicative example of the innovation work undertaken by students in the first cohort. At the outset participants chose areas of their work where they hoped to improve and which would form the basis of the series of learning activities. Not surprising given the similarity in background of the cohort there was a degree of overlap in the types of projects chosen. In broad terms these could be described in the following terms:

- Improving the project management of collaborative work within teams, with industry and other academic research groups (6 people).

- Technical instrument development and scale-up (3 people).

- Exploring professional roles in University Knowledge Transfer (1 person).

John (name anonymised) chose to develop a "Cell Separator" that could be used during fracture repair surgery within an operating theatre itself. Recent advances in the field of microfluidics, have seen a proliferation in techniques designed to isolate cells and John's own research had identified over 60 different techniques available commercially or experimentally. Of these only 3 had been commercialised, highlighting the difficulties in designing devices for cell therapies which show efficacy, safety and cost effectiveness in a clinical environment. On the basis of his participation in the programme and prompted by his own self-study, he identified four particular 
areas to work on: was there a need for a new device? What would be involved in using such a device within a surgical theatre? What were the intellectual property issues surrounding the idea's development? How would he actually progress the project? Each of these questions was addressed as a series of mini-projects that ran concurrently (where possible) during the programme. Some of the topics raised by John (such as intellectual property management) were common to a numbers of students' projects and therefore formed part of the seminar lectures series. However, most of the new understanding he required was generated through his own self-study and tested during meetings of the Action Learning Sets.

The requirement to gain some initial insight on the need for such an instrument prompted an exploration of the use of health economics in medical technology innovation. As well as attending a seminar lecture introducing the topic, John also signed up for a separate course on this subject. Following these initial knowledge 'inputs' he made a study of factors like NHS spend, non-union fracture rates and costs and population dynamics. In addition he assessed scientific publication rates and interviewed clinical sales representatives, surgeons and nurses about their practice and requirements for clinical devices. Finally he attended a daylong symposium on the management of long bone non-union fractures chaired by experienced orthopaedic surgeons. These ideas for gaining some understanding of need were the student's own. He was not following some prescription offered during a lecture, but rather created his own plan of action suggested by his own self-study and 'tested' in discussions with peers during the Action Learning Sets.

The challenge of understanding how his separator might work within the routines of a surgical operation was tackled by undertaking a short ethnographic study. John had never heard of 'ethnography' and simply wanted to observe a surgical 
operation in progress. Upon simply been informed that there was a whole literature on the research method of ethnography he was able to prepare and respond to his findings in a more structured manner. In his own words we can get a sense of the apparently deep insights he gained:

\begin{abstract}
"Whilst viewing this procedure was clinically valuable, it was also interesting to see where a device would be located and as this is likely to be outside of a sterile area the device would need to be a closed system to prevent infections entering. In addition it was interesting to note that the procedure lasted over five hours and cells were extracted for sorting over two hours before they were needed. This is important because it gives an indication of the timescales involved and how quickly the device will need to perform cell separations. However an important and previously neglected finding was how potentially the most important people for the success or failure of clinical cell separation devices are theatre nurses. This is because surgeons, although they extract the original cells, are restricted by the theatre environment and cannot move to another part of the room to perform the separation without needing to change gloves and other difficulties. Therefore theatre nurses perform the separation, meaning that if it worked for them, then acceptance of a new device is likely to be greater. Indeed this was the case with the cell separator being trialled during the operation I observed, where the nurses were given aspirated bone marrow and then performed the separation. However in this instance the device appeared to be difficult to use, requiring precise pipetting and careful manipulation, which could be disturbed and necessitate another separation and one nurse was quoted as saying the device 'is not much cop' and 'gets in the way'. This finding of nurse compliance has been observed previously but is not something I had considered".
\end{abstract}

The other topics appear more routine by comparison with the above activity: project management and intellectual property (IP) management. However, progress was made through a study of these topics that spoke to more personal factors impacting his development. Running repeated rounds of the critical reflection routines described earlier reinforced enduring concerns about personal confidence and the risk of becoming distracted through a natural curiosity towards alternative approaches. The 
presence of these personal factors was never far 'below the surface' of John's reviews of project progress. His work on IP and project management allowed him to work through these issues. In the case of the former becoming familiar with the patent approval process and speaking with patent attorneys allowed him to clarify questions about the timing and content of research publication; thereby addressing the dual priorities (for him) of achieving publications to boost his confidence whilst still progressing his new product idea. Learning and applying the techniques of project management led, in John's own view, to better project planning and keeping him focussed rather than becoming lost in the exploration of new ideas.

The progression of John's thinking and action during the programme was very accomplished. The innovation ideas and practices he needed were researched, discussed and tested at the time he needed them. The flexibility of the action learning approach allowed this, whilst keeping him grounded through the regular critique of the suitability and effectiveness of the actions he was taking.

\section{Challenges for Students with this Approach to Learning}

The exemplars of student progress presented in this paper belie the effort required by young scientists in coming to terms with a literature they are not used to, and especially with a pedagogy that requires them to engage with it more actively that a conventional lecture-based approach. As one student noted:

\footnotetext{
"Initially I was sceptical of the usefulness of the [management] literature, mainly because the majority of that that I read was business focused and I struggled to relate this to my research career as I have never had any desire to enter the world of 'for profit"'.
} 
The challenge was not to argue against such scepticism, but rather make it productive through the repeated use of critical reflection routines. In the words of the same student:

"I found it was a challenge to accept the qualitative nature of conclusions, and I felt that some of the ideas were so abstract they did not make any sense. It was only with continued reading and delving back into some of the [reflection routines], such as Toulmin, that I could grasp the concepts"

Such ambiguities speak to the expectations that many students revealed concerning the taught content of the programme. Prior to the commencement of the programme the majority of participants thought that more general management topics, such as project management and leadership were to be covered more extensively, and presented as a series of "best practice" prescriptions. Crucially, whilst these topics were covered, they were not presented in terms of normative guidance that had been expected. The programme's approach of providing a route into such literature via key readings, and encouraging a critical analysis of that literature was an approach the students found difficult. They would have preferred more conventional lectures, but whether this would have helped their subsequent critique of their own practice is a moot point.

A significant issue described by the majority of participants in cohort one was the difficulty in identifying their 'problems' to work on in the exercises and portfolio. This was especially problematic for post-doctoral participants who were very early career, such as those in the first or second year of post-doctoral work. (This has now been remedied to a large extent by exclusion of early-career post-doc applications to the programme). As students started to apply critical reflection tools on their own 
innovation practice, they reported finding the experience ambiguous and confusing. In attempting the critical thinking routines outlined earlier, then the critique of rhetoric and tradition sat most comfortably with the students. Their scientific training meant that they were comfortable challenging both the logical structure of their thinking and question the traditional way innovation had been conducted in their situation. They were less effective in pursuing the critiques of authority and knowledge. In the main we attribute this to their position and age. All employed on fixed-term contracts, it should not be surprising that there is a degree a reticence in questioning the senior academics and managers with whom they work. Also, having learnt their particular practice of innovation in one setting surrounded by a largely homogeneous group of well-educated peers, it is perhaps forgivable that the contextualised nature of the knowledge they create is difficult to grasp. In noting these difficulties we must acknowledge that this pedagogy may not suit everyone's style. It was certainly the case that a number of people preferred the (relatively) passive receipt of knowledge via lectures, rather than the more challenging discussions of the Action Learning Sets.

Finally, a challenge for maintaining the learning momentum from participating in the programme, is how to habitualise the routines of critical reflection. Many students in their final assignments remarked on the value they had derived from being encouraged to reflect on their practice, and how they hope to make time for reflection in the future. However, whilst the aspiration is not in doubt, few actually moved beyond this aim and suggested concrete actions for making the time for doing so and institutionalising it in their and others' practice of innovation.

\section{Challenges for Tutors with this problem-centred, learner-centred approach to Learning}

The programme was run by two tutors experienced in conventional business school 
teaching methods and a visiting professor with significant experience of running action learning programmes with professional managers. The reflections of the tutors have been drawn upon in this sub-section to identify some of the major challenges of the approach compared to the more traditional teaching methods.

Inevitably with user-centric learning, the syllabus is to a degree emergent, it relies on the student being able to articulate their interests and needs in order to guide the provision of formal lectures and other inputs (e.g. readings). As already noted, during the early stages of the programme this input was limited (the students did not know what they did not know) and the tutors relied on their own sense of what formal innovation topics were required. In the delivery of such sessions care was needed to use an appropriate vocabulary and methodology when explaining key management and innovation terms. The cohort comprised sophisticated and advanced learners but ones whose background contained relatively little business literature. Students were quick to learn, but only after what, in a business school, might be considered very basic terms and contexts had been explained. This required the tutors to constantly review the language and concepts they used in lecture material. In some cases, the relatively 'vague', often qualitative nature of research in the social sciences proved problematic for those steeped in the hard sciences when evidencing the value of well-established management tools, techniques or theory.

As the group became more knowledgeable they began to request more input on specific subjects. This required the rapid development of new teaching materials and the recruitment of external speakers - a significant investment of time and energy which may not necessarily be applicable to any future cohort on the programme. Equally a tension emerged between the requirements of individuals interested in increasingly specific subjects, and the need to run lectures for the entire group. The balance of 
formal learning arguably moved from the seminar lectures to self-study and one-to-one action learning support.

The tutors noted that on occasion the programme appeared to stall, searching for a new direction in terms of areas of interest and teaching. In many more traditional teaching modes, the momentum for a course is typically in the hands of the tutor, deciding what, when and how information is provided: something that can be refined over time with new cohorts. Arguably such momentum is reassuring for both tutor and students: tutors know what is coming next and are prepared, students feel that the tutor knows what they are doing and is expert in delivering such programmes. By contrast, in the action learning approach chosen for this programme, momentum is entirely the result of interaction of students who are often new to the subject and the pedagogy, and tutors not necessarily versed in the often very specific issues and problems which emerge that students want to research and discuss. This lead to what one of the tutors noted as a slightly 'uncomfortable' experience at certain points, when confidence in the overall process appeared to diminish (for both students and tutors). At such points new directions had to be sought and momentum in the programme re-established. This required a certain tolerance of such interludes, and arguably a greater risk appetite amongst the students and tutors than might normally be the case with conventional pedagogies.

\section{Concluding Remarks}

In this paper we have discussed a programme in innovation management that was aimed at early-career medical scientists, and which was founded on a pedagogy that included a critical reflective component and peer learning. We have introduced the thinking tools that we employed to help students to structure their reflections in a manner that offers 
them fresh insight of their views on innovation management; how these were formed and how they might change. Exemplars of student's work were presented along with findings that touch on the effectiveness of the programme and its pedagogy. We noted that it was not an easy programme to operate. As with other attempts to introduce action learning into the HE curriculum (e.g. Boak, 2011), the ambiguity in sensing progress (compared to a conventional content driven curriculum) made for an uncomfortable experience that is perhaps not for everyone. In particular, the participants in our programme were their own 'experts' in a discipline that has scientific rigour at its heart. As tutors, our preferences were oriented towards a social science that did not provide easy answers to mostly human endeavour in a complex world.

Time and resource intensive, it requires tutors that are both responsive to emerging knowledge needs and reflexive in their own tutoring. However, when it works, then it works amazingly well: half of the first cohort has reported new positions/changes in career trajectory that they attribute, in part, to the learning they gained through the programme. At its core, the programme was concerned with innovation management, a subject in its own right, with its own body of expert knowledge, or P. However, we were just as concerned with how the programme could make a contribution to the practice of innovation by practitioners who needed to understand their positions as managers in a practice context. There was the science that was an inevitable part of what was being innovated but when it came to managing such a process, another understanding was needed, especially when the problems were concerned with human activity. As one very famous scientist, Einstein once said, 'We cannot solve our problems with the same thinking we used when we created them'. Our task was to enable a difference in this process through critical thinking and this involves switching their paradigm of management development from learning a set of normative 
prescriptions, to one that involves coming to a fuller awareness of what they do, when they do innovation. As one of our students concluded, “'I've learnt that innovation management is about critical thinking around ideas, open communication and collaboration with others.'

\section{Acknowledgements}

The authors would like to express our thanks for the students who participated in both the informal pilot and first two formal presentations of this programme. Not only did we find our interactions very enjoyable, but also thank them for the new insights they gave us on both the use of these critical reflection routines and the practice of science-led innovation. We would particularly like to thank those students who have allowed us to reproduce their work in this paper. Other than the direct quotes, we have written the descriptions of their work, and any errors with incorrect explanations of the technical details of their innovation work are our own. 
1

2

3

4

5

6

7

8

9

10

11

12

13

14

15

16

17

18

19

20

21

22

23

24

25

26

27

28

29

30

31

32

33

34

35

36

37

38

39

40

41

42

43

44

45

46

47

48

49

50

51

52

53

54

55

56

57

58

59

60

Figure 1. The "Professional Innovation Management" programme.

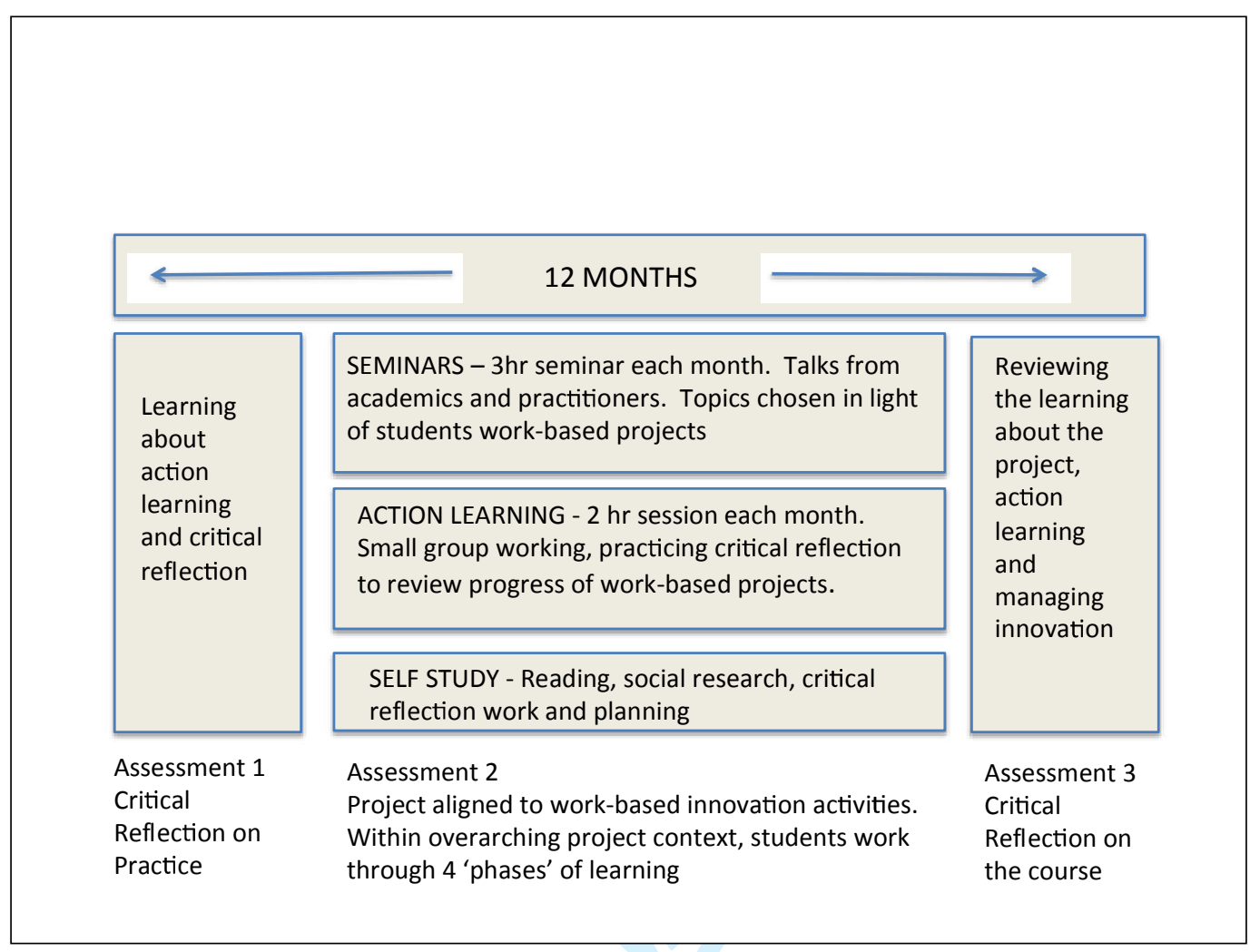


Figure 2 - Charting the patterns, insights and puzzles amongst stories of practice (Source: Gold et al., 2006)

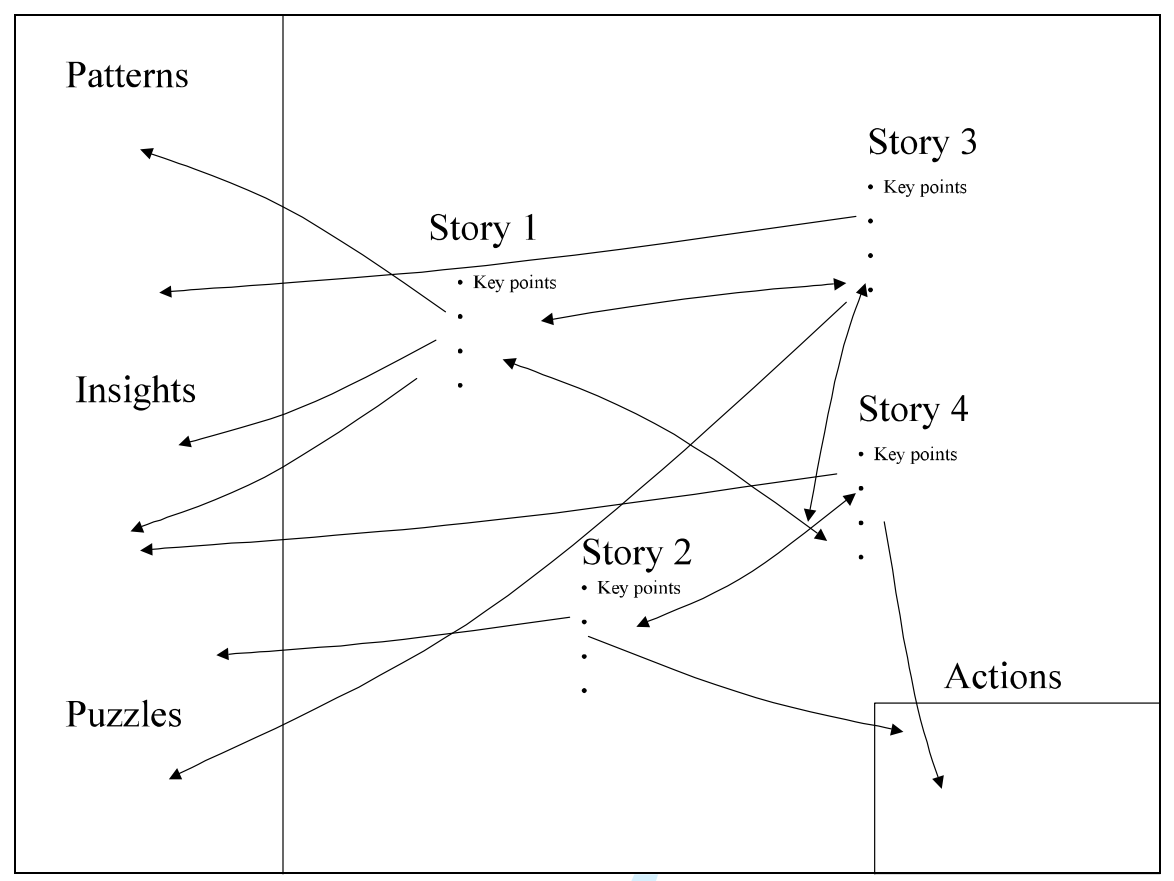


Figure 3 - One Students charting of aspects of their innovation practice (Source:

Student's first Assignment)

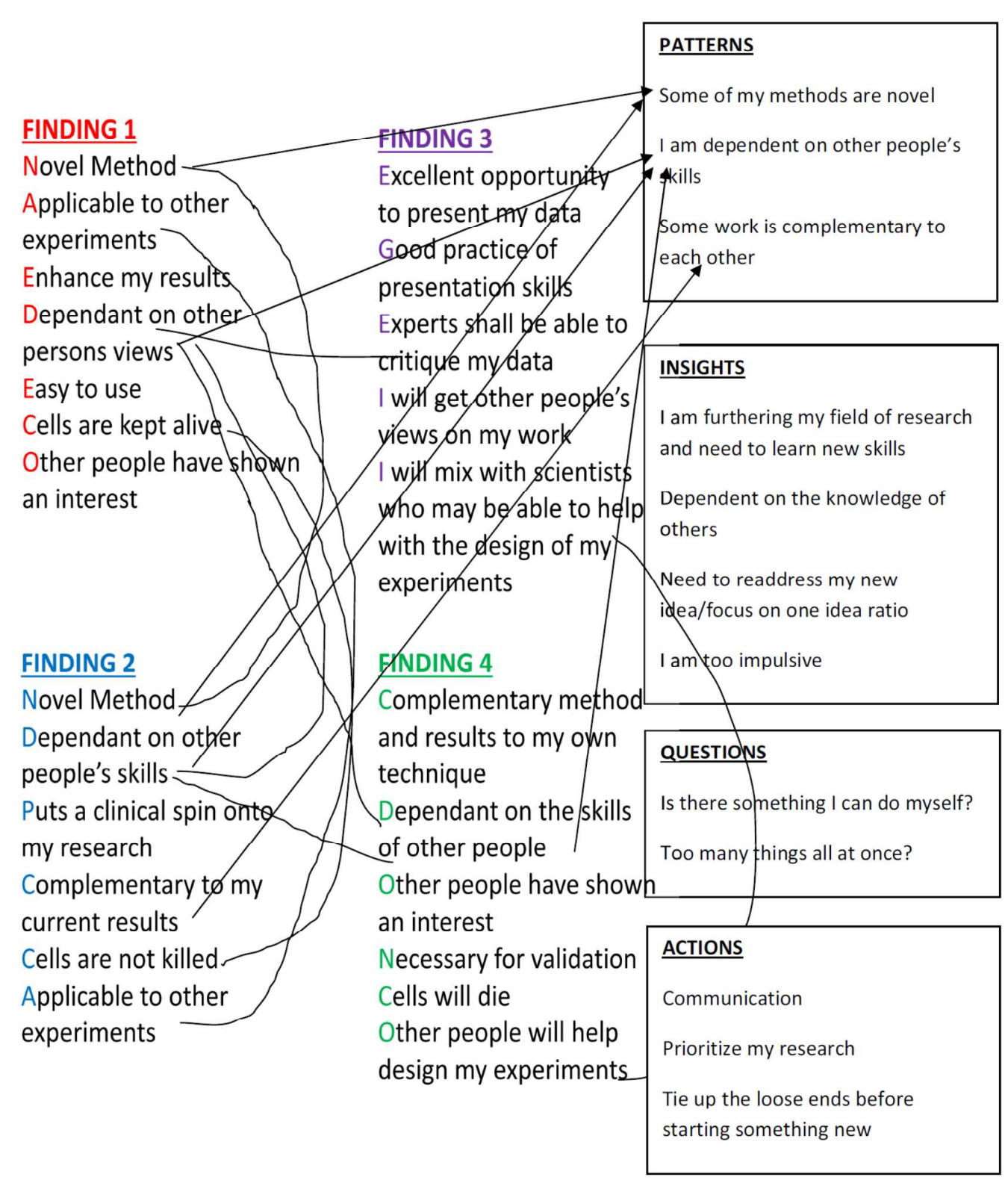


References

Anderson, L., and R. Thorpe. "Putting the ' $\mathrm{C}$ ' in Hrd." In Critical Human Resource Development: Beyond Orthodoxy, edited by C. Rigg, J. Stewart and K. Trehan. London: Financial Times/Prentice Hall, 2007.

Boak, G. "Blending Q and P: Incorporating Action Learning in a Master's Programme." Action Learning: Research and Practice 37 (2011): 728-43.

Brook, C., M. Pedler, and J. Burgoyne. "A Protean Practice? Perspectives on the Practice of Action Learning." European Journal of Training and Development 37 (2013): 728-43.

Eden, C., S. Jones, and D. Sims. Messing About in Problems: An Informal Structural Approach to Their Identification and Measurement. Oxford: Pergammon Press, 1983.

Gold, J., D.J. Holman, and R. Thorpe. "The Role of Argument Analysis and Story Telling in Facilitating Critical Thinking." Management Learning 33, no. 3 (2002): 371-88.

Gold, J., M. Rix, R. Thorpe, and R. Holt. "Now I See It: Seeing an Aspect in Management Learning." In European HRD Conference. Tilburg, 2006.

Harrison, P., and C. Edwards. "A Partnership Approach to Action Learning within a Master's Educational Programme." Action Learning: Research and Practice 9 (2012): 45-50.

Lawless, A. "Action Learning as Legitimate Peripheral Participation." Action Learning: Research and Practice 5 (2008): 45-50.

Mingers, J. "What Is It to Be Critical? Teaching a Critical Approach to Management Undergraduates." Management Learning 31, no. 2 (2000): 219-37.

Mumford, A. "Learning in Action." Industrial and Commercial Training 27 (1995): 3640.

Pedler, M. Action Learning for Managers. Aldershot: Gower Publishing, 2008. ed. Action Learning in Practice. 4th ed. ed. Aldershot :: Gower, 2012.

Revans, R. The Abc of Action Learning: A Review of 25 Years of Experience. Salford: Salford University, 1978.

—. The Origins and Growth of Action Learning. Bromley: Chartwell-Bratt, 1982.

Toulmin, S. The Uses of Argument. Cambridge: Cambridge University Press, 1958.

Trehan, K., and M. Pedler. "Animating Critical Action Learning: Process-Based Leadership and Management Development." Action Learning: Research and Practice 6 (2009): 35-49. 
1

2

3

4

5

6

7

8

9

10

11

12

13

14

15

16

17

18

19

20

21

22

23

24

25

26

27

28

29

30

31

32

33

34

35

36

37

38

39

40

41

42

43

44

45

46

47

48

49

50

51

52

53

54

55

56

57

58

59

60
Trehan, K., and C. Rigg. "Working with Experiential Learning: A Critical Perspective in Practice." In The Handbook of Experiential and Management Education, edited by M. Reynolds and R. Vince. Oxford: Oxford University Press, 2007.

Wittgenstein, L. Philosophical Investigations. Oxford: Basil Blackwell, 1953. 